\title{
Studies of phenolic and aromatic profile of Busuioacă de Bohotin wines
}

\author{
Lucia Cintia Colibaba $^{1}$, Valeriu V. Cotea ${ }^{1}$, Florin Gabriel Lacureanu ${ }^{2}$, Stefan Tudose-Sandu-Ville ${ }^{1}$, Liliana Rotaru ${ }^{1}$, \\ Marius Niculaua ${ }^{3}$, and Camelia Elena Luchian ${ }^{1}$ \\ ${ }^{1}$ University of Agricultural Sciences and Veterinary Medicine "Ion Ionescu de la Brad" Iasi, 3 M. Sadoveanu Alley, \\ 700490 Iasi, Romania \\ ${ }^{2}$ Licorna Winehouse, Gura Vadului, Mizil, Prahova, Romania \\ ${ }^{3}$ Oenological Research Center, Romanaian Academy - Iasi Branch, 9 M. Sadoveanu Alley 700490 Iasi, Romania
}

\begin{abstract}
The Busuioacă de Bohotin grapes were harvested from Pietroasa vineyard, in Dealu Mare viticultural area, in 2013. The wines were obtained by applying modern technologies: cryomaceration, microwave maceration, ultrasound maceration, rotative-tanks maceration, etc, after which the normal technological process was followed. These samples are characterised by specific volatile compounds (terpenic compounds, esters, alcohols and some fatty acids) and polyphenols (anthocyans, flavanols, favonols, stilbens and other phenolic compounds) which were evaluated in order to understand the influence of the applied technologies upon wine making strategies. The wine phenolic compounds were carried out with high-performance liquid chromatograph (HPLC) Shimadzu equipped with two chromatographic columns Merck Chromolith Performance RP-18. The wine aroma compounds were analysed by a Shimadzu GC-2010, coupled with a QP2010 Plus spectrophotometer.
\end{abstract}

\section{Introduction}

In Romania, aromatic wines are well represented, due to their aroma: Muscat Ottonel, Tămâioasă românească and Busuioacă de Bohotin are cultivated in many local vineyads: Târnave, Dealu Mare (Pietroasa), Drăgăşani, Murfatlar, Cotnari, Huşi (Bohotin centre), Iaşi (Tomeşti centre) and more. The colour of rosé wines varies on a large segment, from a pale pink (onion skin), to a light red. There are no well-defined limits for the colour of rosé wines differing according to viticultural area, used grape variety, technological process of wine-making.

A special place among rosé Romanian wines is occupied by Busuioacă de Bohotin that can easily rival cosmopolitan varieties not only through its phenolic quality but also through its aroma (Vărăticeanu Gh. et al., 1998). According to the annual climatic conditions, the obtained wines have a colour intensity that varies between 0.048 $0.325 \mathrm{~nm}$ and have a faint and very pleasant rose-like aroma.

Busuioacă de Bohotin grape variety has been cultivated in Romanian vineyards for a long time, before the phylloxera attack, being considered therefore a local grape variety. It seemingly originates either from ancient Greece, as a close relative of Tamaioasa românească, another aromatic Romanian grape variety, either from France, from the very similar Muscat violet de Frontignan. As a rosé and an aromatic grape variety, Busuioacă de Bohotin wine has always been highly appreciated by consumers and has been much adulterated due to the small cultivated surface (around 1000 ha) in the whole country.

Busuioacă de Bohotin, like Tămâioasă românească, but more so, has a specific wine-making process. Harvesting of grapes should be done at over-ripening, when the sugars content is higher than $240 \mathrm{~g} / \mathrm{L}$. The rosé colour and the unforgettable aroma are obtained by skin maceration at a low temperature for 2-3 days. Fermentation continues until it stops naturally, before all sugars are consumed. Therefore, Busuioacă de Bohotin should be a sweet wine, with an alcoholic concentration of 12-12.5 vol.\%, total acidity of 6-7 g/L tartaric acid and remanent sugars of 40-60 g/L. Busuioacă de Bohotin wines can be consumed young, but most appreciated they are after 5-8 years of aging [1].

A problem for many to pinpoint, the colour of Busuioacă de Bohotin wines can range from pink with violet hues in young wines to pale orange (onion skin) in wines obtained with a short maceration period or wine that has been aged for 3-5 years.

The aroma is a very pleasurable blend of roses, basil, wild strawberries, similar in profile with that of Tămâioasă românească (less "refined"), strongly influenced by the content of phenolic compounds, which gives it a more vigorous spine bone.

The main aim of this study is to analyse phenolic compounds as well as volatile compounds from samples of Busuioacă de Bohotin wines, experimental as well as commercial, in order to try and pinpoint specific traits and to be able to fight against adulterated wines with a more clear background.

\section{Material and method}

Busuioacă de Bohotin grapes were harvested from Pietroasa vineyard in 2009 , processed accordingly to the general technology for aromatic wines, differences appearing in the maceration stage. Various methods (different skin maceration periods - 12 hours, 18 hours, 72 hours, ultrasounds maceration for 15 minutes, microwave maceration 
at $350 \mathrm{~W}$ and $650 \mathrm{~W}$, cryo-maceration and maceration in rotative tanks) were used and 8 experimental samples were obtained.

Also, a number of 8 commercial wine samples labelled as Busuioacă de Bohotin were taken into analysis, in order to be able to compare their anthocyanic fingerprint as well as their aroma profile.

\subsection{Phenolic compounds analysis method}

The samples were processed with a Shimadzu HPLC connected to a PC via LAN. As A eluent, a solution of water:formic acid:acetonitrile 87:10:3 was used, while, as B eluent, water:formic acid:acetonitrile 40:10:50, B eluent increasing from $6 \%$ to $60 \%$. For each chromatogram, the relative proportions of anthocyans were identified and calculated: delphinidin-3-monoglicoside (Dp), cyanidin3-monoglicoside (Cy), petunidin-3-monoglicoside (Pt), peonidin-3-monoglicoside (Po), malvidin-3-monoglicoside $(\mathrm{Mv})$, peonidin-3-monoglicoside acetilate (Po-a), malvidin3-monoglicoside acetilate (M-a), peonidin-3-monoglicoside cumarilate $(\mathrm{Po}-\mathrm{cm})$, malvidin-3-monoglicoside cumarilate (M-cm).

Analysis of phenolic acids (galic, syringic, coumaric) as well as resveratrol was achieved by using a after a method presented by M. Castellari [2]. As B eluent, a solution of $1 \%$ methanol in which phosphoric acid was added ( $\mathrm{pH}=2.4$ ) was used, while, as $\mathrm{C}$ eluent, an aqueous solution of $50 \%$ methanol in which phosphoric acid was added ( $\mathrm{pH}=2.8$ ) was used. The columns system is composed of a precolumn Chromolith Guard Cartridge $5 \mathrm{~mm} \times 4.6 \mathrm{~mm}$ and two columns Chromolith Performance RP-18 endcapped $100 \mathrm{~mm} \times 4.6 \mathrm{~mm}$ produced by Merck.

The anthocyanic profile of wines can give information regarding the grape variety used, being an important index for determining the wines' authenticity. There is, however, a limit regarding drawing a parallel between the anthocyanic fingerprint and the wines' authenticity, because, especially in red wines, after 2-3 years after bottling, only traces of free anthocyans remain, able to be analysed by HPLC [3].

The wine's anthocyanic profile expresses the participation percentage of free acetylated and cumarilated anthocyans, important for the wine colour. During skin maceration and wine ageing, the acylated anthocyans are more stable and resist to condensation, therefore, in order to establish a correct anthocyanic profile, the sum of acetylated and cumarilated anthocyans and the ratio between acetylated and cumarilated anthocyans were calculated.

\subsection{Aroma compounds analysis method}

The wine samples were, previous to GC-MS analysis, extracted with LiChrolut EN/RP-18 (40-120 $\mu \mathrm{m}) 100 \mathrm{mg}$ şi RP (40-63 um) $200 \mathrm{mg}, 6 \mathrm{ml}$ Standard PP and LiChrolut EN (40-120 $\mu \mathrm{m}) 500 \mathrm{mg}, 6 \mathrm{ml}$ Standard PP.

$20 \mathrm{~mL}$ of wine sample was percolated through a SPE cartridge with $\mathrm{C}^{18}$ bed. This was first conditioned by passing $10 \mathrm{~mL}$ dichloromethane, $10 \mathrm{~mL}$ methanol and $10 \mathrm{~mL}$ aqueous solution with ethanol $13 \% \mathrm{v} / \mathrm{V}$. The bed was dried by passing air through it. The retained compounds were percolated by passing $2 \mathrm{~mL}$ of dichloromethane,
$1000 \mu \mathrm{L}$ extract being then injected into a Shimadzu GC-2010 coupled with a mass-spectrometer QP2010 Plus.

Analysis parameters: oven temperature: $35^{\circ} \mathrm{C}$; injector temperature: $220^{\circ} \mathrm{C}$; splitless injection mode; carrying gas: He; carrier gas speed: $1 \mathrm{~mL} / \mathrm{min}$; oven temperature program: initially, $35^{\circ} \mathrm{C}$ for $5 \mathrm{~min}, 4^{\circ} \mathrm{C}$ per minute up to $250^{\circ} \mathrm{C}$, where it stays for 13.25 minutes; ion source temperature: $250^{\circ} \mathrm{C}$; interface temperature: $250^{\circ} \mathrm{C}$; analysed mass domain: 50-200 m/z; detector sensibility: $1.05 \mathrm{~V}$.

Aroma compounds were determined by NIST 08, Wiley 08 and SZTERP libraries.

\section{Results and discussions}

The participation percentages of free anthocyans from young Busuioacă de Bohotin are presented in Table 1 .

Malvidin is found in the highest proportion in all analysed samples, followed by petunidin and peonidin. Cyanidin is found in the smallest proportion. The first three maceration variants have similar proportions of participations percentages, even if the total anthocyans differ from a quantitative point of view. The majoritary participant of wine colour is malvidin.

Peonidin and petunidin, who imprint the colour red to wines, are of $8.31-29.65 \%$ and respectively $0.18-2.85 \%$; the maximum value for peonidin was found in cryo-macerated samples while for petunidin, the highest values were found in samples macerated in ROTO $®$ tanks.

In grapes, delphinindin represents, during maturation, $5-7 \%$ of the total of anthocyans. In the experimental samples, delphinidin has sub-unitary values of $0.13-0.86 \%$.

Cianidin, who imprints to wines their crimson colour, is found in small quantities in all experimental variants, except wines obtained with classical maceration for 72 hours, where the value of $7.05 \%$ was registered. These wines have the most intense colour, which may be evaluated as atypical for Busuioacă de Bohotin wines.

For establishing the complete anthocyanic profile, the acetylated and cumarilated derivatives were also analysed (Table 2).

Table 1. Anthocyan profile of Busuioacă de Bohotin 2009 and 2010 wines (participation \%).

\begin{tabular}{|l|l|l|l|l|l|}
\hline \multirow{2}{*}{ Trial wine samples } & \multicolumn{5}{|c|}{ Free anthocyans } \\
\cline { 2 - 6 } & Dp & $\mathbf{C i}$ & $\mathbf{P t}$ & Po & $\mathbf{M v}$ \\
\hline BB 12 h maceration & 0.54 & 1.94 & 2.02 & 12.41 & 79.22 \\
\hline BB 18 h maceration & 0.64 & 0.79 & 2.66 & 8.31 & 75.03 \\
\hline BB 72 h maceration & 0.53 & 7.05 & 2.59 & 15.21 & 68.01 \\
\hline BB cryo maceration & 0.41 & 0.22 & 0.18 & 29.65 & 56.34 \\
\hline BB 15' U maceration & 0.18 & 0.22 & 0.65 & 29.61 & 56.54 \\
\hline $\begin{array}{l}\text { BB 350 W } \\
\text { maceration }\end{array}$ & 0.16 & 0.87 & 0.37 & 25.81 & 59.33 \\
\hline $\begin{array}{l}\text { BB 650 W } \\
\text { maceration }\end{array}$ & 0.13 & 1.05 & 0.84 & 25.22 & 65.29 \\
\hline $\begin{array}{l}\text { BB rotative tanks } \\
\text { maceration }\end{array}$ & 0.86 & 1 & 2.85 & 11.51 & 72.3 \\
\hline
\end{tabular}


Table 2. Acylated derivates of peonidin and malvidin of Busuioacă de Bohotin wines (participation \%).

\begin{tabular}{|c|c|c|c|c|c|c|}
\hline \multirow[t]{2}{*}{$\begin{array}{l}\text { Trial wine } \\
\text { samples }\end{array}$} & \multicolumn{2}{|c|}{$\begin{array}{c}\text { 3-gl- } \\
\text { acetilat }\end{array}$} & \multicolumn{2}{|c|}{$\begin{array}{c}\text { 3-gl- } \\
\text { cumarilat }\end{array}$} & \multirow[t]{2}{*}{$\begin{array}{c}\sum(\% \text { acet }+ \\
\% \text { cum })\end{array}$} & \multirow[t]{2}{*}{$\begin{array}{l}\sum \% \text { acet/ } \\
\sum \% \text { cum }\end{array}$} \\
\hline & Po & $\mathrm{Mv}$ & Po & $\mathrm{Mv}$ & & \\
\hline $\begin{array}{l}\mathrm{BB} 12 \mathrm{~h} \\
\text { mac. }\end{array}$ & 0.07 & 3,41 & 0.15 & 5.24 & 3.87 & 0.65 \\
\hline $\begin{array}{l}\text { BB } 18 \mathrm{~h} \\
\text { mac. }\end{array}$ & 0.14 & 4.04 & 0.86 & 7.53 & 12.57 & 0.50 \\
\hline $\begin{array}{l}\text { BB } 72 \mathrm{~h} \\
\text { mac. }\end{array}$ & 0.15 & 2.41 & 0.22 & 3.83 & 6.61 & 0.89 \\
\hline $\begin{array}{l}\text { BB cryo } \\
\text { mac. }\end{array}$ & 0.17 & 2.38 & 0.20 & 3.81 & 6.56 & 0.63 \\
\hline $\begin{array}{l}\text { BB } 15^{\prime} \mathrm{U} \\
\text { mac. }\end{array}$ & 0.16 & 4.14 & 0.88 & 7.59 & 12.77 & 0.50 \\
\hline $\begin{array}{l}\text { BB } 350 \mathrm{~W} \\
\text { mac. }\end{array}$ & 0.42 & 4.26 & 0.97 & 7.81 & 13.46 & 0.51 \\
\hline $\begin{array}{l}\text { BB } 650 \mathrm{~W} \\
\text { mac. }\end{array}$ & 0.26 & 2.60 & 0.71 & 3.90 & 7.47 & 0.62 \\
\hline $\begin{array}{l}\text { BB } \\
\text { rotative } \\
\text { tanks mac. }\end{array}$ & 0.38 & 3.02 & 0.96 & 7.11 & 11.48 & 0.42 \\
\hline
\end{tabular}

The acylated forms are found in very small quantities and are specific to each grape variety but they can also be influenced by the applied technology. Therefore, the acetylated and cumarilated forms of peonidin and malvidin were analysed. The results show that the quantity of cumarilated anthocyans are higher, the ratio between the acetylated and cumarilated ones is subunitary, a specific index for variety typicity. These values are in accordance with other specific information regarding Romanian black grapes varieties $[4,5]$.

The commercial samples were produced between 2007 and 2009 from different Romanian viticultural areas, with physico-chemical parameters similar to the experimental ones, labelled from V1 to V8.

$\mathrm{V} 2$ and V4, after analyzing the anthocyanic print, were considered nonspecific for Busuioacă de Bohotin wines.

The analysis method used for phenolic compounds (Table 3) was optimized in order to obtain information on almost all compounds of physiological interest for the human body (protocatehic acid, p-hidroxibenzoic acid, vanillic acid, galic acid, syringic acid, gentisic acid, cafeic acid, chlorogenic acid, p-cumaric acid, ferulic acid and sinapic acid) resulted either from biosynthesis process in the plant, either during fermentation.

Regarding some acids that are known to originate from grapes during biosynthesis process (protocatehic acid, galic acid, p-cumaric acid, cafeic acid and ferulic acid) it was proven that the technological method favours their accumulation in wine when using tougher extractive procedures (rotating tanks) as can be seen in Busuioacă de Bohotin wines.

Among the 11 analysed phenolic acids, the highest concentration is registered for protocatehic acid, with values of tens of $\mathrm{mg} / \mathrm{L}$, while others, such as vanilic acid, chlorogenic acid, cafeic acid or p-cumaric acid have unitary values. The others (syringic acid, gentisic acid and

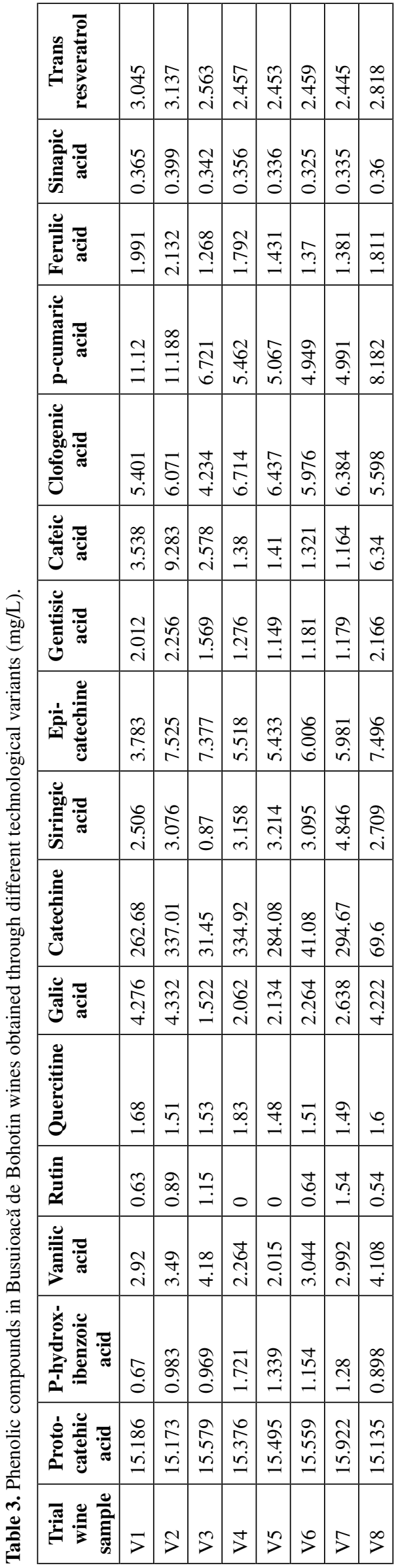


Table 4. Anthocyan profile of Busuioacă de Bohotin 2007-2009 wines - commercial samples (participation \%).

\begin{tabular}{|l|l|l|l|l|l|}
\hline $\begin{array}{c}\text { Trial wine } \\
\text { samples }\end{array}$ & \multicolumn{5}{|c|}{ Antociani liberi } \\
\hline & Dp & Ci & Pt & Po & Mv \\
\hline V1 & 2.98 & 1.46 & 3.98 & 6.63 & 63.47 \\
\hline V3 & 5.92 & 1.09 & 10.78 & 6.12 & 56.56 \\
\hline V5 & 5.90 & 4.78 & 6.06 & 8.24 & 59.45 \\
\hline V6 & 0.21 & 1.81 & 0.37 & 12.49 & 86.75 \\
\hline V7 & 0.18 & 2.15 & 0.35 & 6.21 & 90.22 \\
\hline V8 & 0.19 & 0.46 & 0.73 & 24.38 & 74.05 \\
\hline
\end{tabular}

sinapic acid) are registered in small quantities, being influenced by the technological process.

Some tannins register high values (catechine $337.01 \mathrm{mg} / \mathrm{L}$ in the samples where a 72 hours maceration was applied, $334 \mathrm{mg} / \mathrm{L}$ in the samples obtained through cryomaceration). Epi-catechine has much smaller values, the maximum one, $7.52 \mathrm{mg} / \mathrm{L}$, being registered in the sample where an 18 hours maceration was applied.

Table 4 presents results obtained from determining the participation percentage of free anthocyans in commercial samples.

There are major differences between the participation percentages of free anthocyans: delphinidin has similar values for the three wines (V6,V7,V8) from Dealu Mare Vineyard $(0.18-0.21 \%)$, while the values of the other three wines obtained in various other vineyards differ a lot (2.98-5.92\%). The participation percentage of delphinidin in the experimental wines $(0.13-0.86 \%)$ is similar to those of the first 3 commercial wines, the fact that this parameter is not greatly influenced by different technological processes in wines from the same vineyard is confirmed.

The different results of the participation percentages for delphinidin for the other commercial samples are proof that terroir has profound implications on the anthocyanic print of Busuioacă de Bohotin wines. The fact that delphinidin's participation percentage do not change very much for black and rosé varieties can signify that not all grapes were Busuioacă de Bohotin variety.

The same is partially correct in the case of petunidin, with values between $0.37 \%$ and $10.78 \%$ in all commercial samples; the experimental values had values ranging from $0.18 \%$ to $2.85 \%$, similar to wines obtained in Dealu Mare Vineyard, wines from other areas presenting big discrepancies regarding the participation percentage of this anthocyan in the profile (3.98-10.78\%).

Cyanidin, the anthocyan with the smallest percentage of the free anthocyans has values between $0.46 \%$ and 4.78\%; the values registered for cyanidin in the commercial samples are similar to those from the experimental samples $(0.22-7.05 \%)$.

Peonidin had quite close values (6.12-24.38\%) to the data obtained in the experimental samples (8.31-29.65\%), but in larger intervals; taking this into account, the participation percentages if this anthocyan are influenced by the technological process rather than by the genetic potential of the grape variety. The same is true for malvidin, where the participation percentage ranges from $59.45 \%$
Table 5. Acetylated derivates of peonidin and malvidin of Busuioacă de Bohotin 2007-2009 wines - commercial samples (participation \%).

\begin{tabular}{|c|c|c|c|c|c|c|}
\hline \multirow{2}{*}{$\begin{array}{c}\text { Trial } \\
\text { Wine } \\
\text { samples }\end{array}$} & \multicolumn{2}{|c|}{$\begin{array}{c}\text { 3-gl- } \\
\text { acetylated }\end{array}$} & \multicolumn{2}{|c|}{$\begin{array}{c}\text { 3-gl- } \\
\text { cumarilated }\end{array}$} & \multirow[t]{2}{*}{$\underset{\%(\% \text { acet }+}{\left.\sum \text { cum }\right)}$} & \multirow[t]{2}{*}{$\begin{array}{l}\sum \% \text { acet/ } \\
\sum \% \text { cum }\end{array}$} \\
\hline & Po & Mv & Po & Mv & & \\
\hline V1 & 1.46 & 13.99 & 1.18 & 4.87 & 21.5 & 2.55 \\
\hline V3 & 1.67 & 11.8 & 1.16 & 4.89 & 19.53 & 2.23 \\
\hline V5 & 1.21 & 8.30 & 1.18 & 4.89 & 15.58 & 1.57 \\
\hline V6 & 0.39 & 9.16 & 1.16 & 4.92 & 15.63 & 1.57 \\
\hline V7 & 0.28 & 8.44 & 1.23 & 4.79 & 14.74 & 1.45 \\
\hline V8 & 0.2 & 9.22 & 1.19 & 4.91 & 15.52 & 1.54 \\
\hline
\end{tabular}

to $90.22 \%$ for all commercial samples, the highest value being registered in the case of V7, from Dealu Mare Vineyard in 2008.

Table 5 presents values of participation percentages of acetylated and cumarilated anthocyans of analysed commercial samples.

The results obtained after analysing commercial Busuioacă de Bohotin wines show that they have a higher quantity of acetylated anthocyans than cumarilated ones, the ratio being over the unit, ranging from 1.45 to 2.55 .

The sum of acetylated and cumarilated anthocyans varies between $14.74 \%$ and $21.5 \%$ according to the vineyard of origin. The wines from Dealu Mare Vineyard (V6, V7,V8) and those from Dealurile Huşilor Vineyard (V5) contain the lowest proportion of acylated anthocyans, approximately $10 \%$ of the anthocyanic profile; the other two samples have a higher quantity of acylated anthocyans (23\% of the total).

Analysing the anthocyanic print, one can say that the commercial wines of Busuioacă de Bohotin variety have a higher percentage of acylated anthocyans (8.8$22.7 \%$ ), compared to wines from other Romanian varieties (Fetească neagră or Băbeasca neagră), having thus a better colour stability during maturation and aging. The percentage of acylated anthocyans is higher in the commercial samples than in the experimental ones, fact that can be explained either by the different maceration procedure, either by the use of various adjuvants, like enzymes.

The aroma profile of the commercial samples was also analysed, from a qualitative point of view. At the same time, area units (AU) of the peak were registered, thus being able to make comments on the quantitative profile of the identified compounds. The GC/MS method identified an average of 28 aroma compounds in Busuioacă de Bohotin commercial samples: 9 esters, 8 superior alcohols, 5 fatty acids, 6 terpens or terpenic derivatives.

Identified superior alcohols (Fig. 1) are: propanol, isobutylic alcohol, 4-methyl 2-pentanol, 3-methyl1-butanol, 1-hexanol, phenyl-ethyl-alcohol. Of the identified esters (Fig. 2), of interest are: isoamyl acetate, fatty acids esters, esters of acetic acid, esters of vanillic and myristic acid (identified only in Busuioacă de Bohotin samples from Tohani - V2 and Verneşti - V4). Identified acids (Fig. 3): acetic acid, butanoic acid, fatty acids (hexanoic, octanoic, n-decanoic) and sorbic acid. The terpens or the terpenic derivatives (Fig. 3) are specific to Busuioacă 


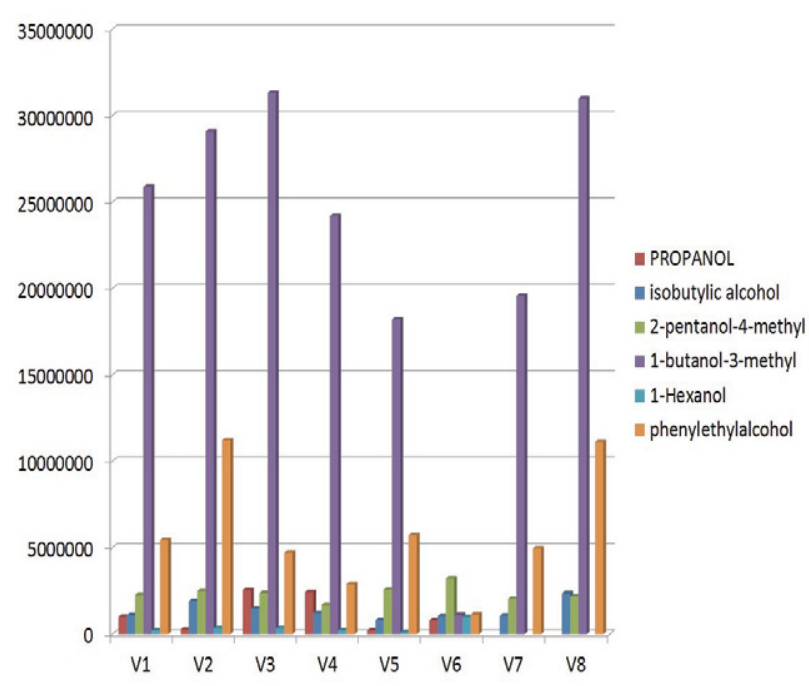

Figure 1. Superior alcohols identified in commercial samples of Busuioacă de Bohotin.

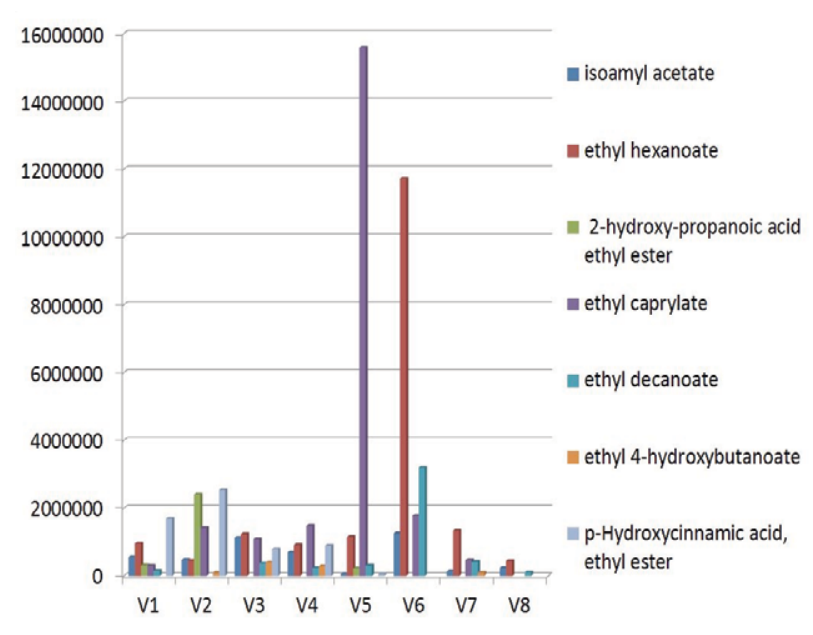

Figure 2. Esters identified in commercial samples of Busuioacă de Bohotin.

de Bohotin wines [6,7]. Linalool, linalyl propionate, neric acid, geranic acid, terpineol and other diols are present.

The Busuioacă de Bohotin commercial samples show a very large pallet of terpenic compounds, the most complex profile being registered in V5, wine from Dealu Mare Vineyard, Pietroasele centre, extremely well known for producing aromatic wines.

\section{Conclusion}

Busuioacă de Bohotin wines promise an interesting development, as they concur in fulfilling two prominent choices in consumers' preference: rosé wines and aromatic wines.

The anthocyan profile analysis proves to be able to identify wines where not only Busuioacă de Bohotin grapes were used for wine-making, fact that is also proven by the aroma analysis, where specific terpenic compounds are either missing or found in very small concentrations.

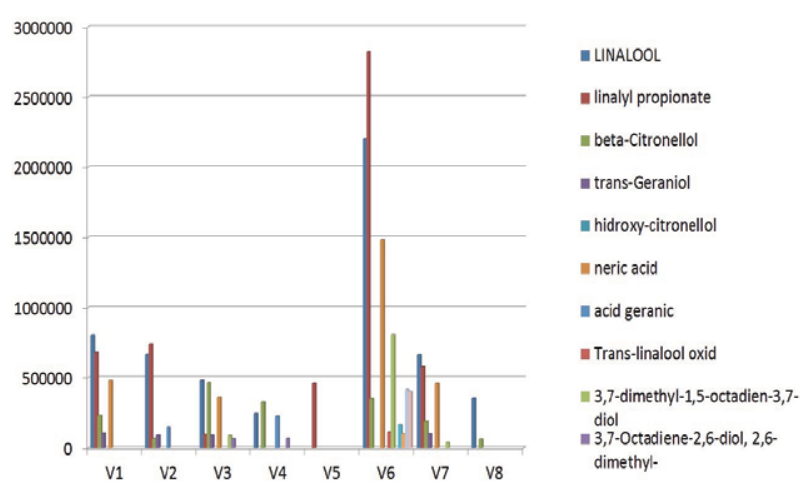

Figure 3. Terpenic compounds identified in commercial samples of Busuioacă de Bohotin.

The aroma profile is characterized by linalool, linalyl propionate, beta-citronellol and neric acid, which are found in the highest concentrations, compounds which are also responsible for the sensorial profile specific literature mentions.

The publishing of this study was made possible with the help of the USAMV Iasi internal research grant 5526/25.04.2013.

\section{References}

[1] V. Stoian, Marea carte a degustării vinurilor, Editura Artprint, București (2001)

[2] M. Castellari, E. Sartini; A. Fabiani; G. Arfelli, A. Amati, Analysis of wine phenolics by high-performance liquid chromatography using a monolithic type column, Journal of Chromatography A, 973, no. 1-2, p. 221-227 (2002)

[3] C. T,ârdea, Chimia şi analiza vinului, Editura Ion Ionescu de la Brad, Iaşi (2007)

[4] C. Zamfir, Studiul autenticității şi tipicității vinurilor roşii obținute din soiuri autohtone, Teză de doctorat, Universitatea de ştiinţe Agricole şi Medicină Veterinară, Ion Ionescu de la Brad", Iaşi (2009)

[5] St. Tudose-Sandu-Ville, Studiul compuşilor fenolici din vinurile roşii obținute prin diferite tehnologii de vinificare în Podgoria Iaşi, Teză de doctorat, Universitatea de ştiințe Agricole şi Medicină Veterinară, Ion Ionescu de la Brad", Iaşi (2012)

[6] C. Colibaba, V.V. Cotea, B. Nechita, M. Niculaua, F. G. Lăcureanu, St. Tudose-Sandu-Ville, Compounds with sensorial character of Tamaioasa romaneasca wines obtained through different maceration technologies, Lucrări ştiințifice U.S.A.M.V. Iaşi, seria Horticultură, 54, electronic ISSN 2069-8275, pg. 347-352, USAMV Iaşi, Facultatea de Horticultură (2011)

[7] C. Colibaba, G. Lăcureanu, V. V. Cotea, St. TudoseSandu-Ville, B. Nechita, Identification of Tămâioasă românească and Busuioacă de Bohotin wines' aromatic compounds from Pietroasa Vineyard, Bulletin of University of Agricultural Sciences and Veterinary Medicine Cluj-Napoca. Horticulture, 66(1), ISSN 1843-5254, p.309-314 (2009) 